\title{
EL FOTÓGRAFO-PICTORIALISTA ANTONIO PORTELA Y EL PINTOR GONZALO BILBAO EN EL MADRID DEL NOVECENTISMO
}

\author{
THE PHOTOGRAPHER- PICTORIALISM ANTONIO \\ PORTELA AND THE PAINTER GONZALO BILBAO OF \\ NOVECENTISMO IN MADRID
}

\author{
Gerardo Pérez Calero \\ Universidad de Sevilla. España \\ gcalero@us.es
}

\begin{abstract}
Este trabajo aborda las relaciones profesionales que unieron en Madrid a dos artistas prestigiosos de la periferia.

Palabras clave: Arte en el Madrid del Novecentismo.

This paper addresses the professional relations that united in Madrid two prestigious artists from the periphery.

Key words: Art in Madrid Novecentismo.
\end{abstract}

A la capital de España, como a las grandes ciudades europeas, acudían desde siglos los creadores de las artes y de las letras en busca de oportunidades para su promoción. Madrid seguía siendo en el tránsito del siglo XIX al siguiente, cuna de artistas y lugar de encuentro, pues la Edad de Plata de la cultura española reclamaba también su liderazgo en la promoción artística como lo tuvo en el Siglo de Oro.

Era frecuente entonces que pintores de la periferia acudiesen a Madrid por dos motivos: Si llegaban como artistas en formación para continuar su aprendizaje habitualmente como estudiantes en la Escuela Especial de Pintura, Escultura y Grabado, dependiente de la Academia de San Fernando, o como copistas en el Museo del Prado; si lo hacían ya como profesionales y sin descartar esta última 
actividad, para competir en las Exposiciones Nacionales de Bellas Artes o para ofrecer sus servicios como retratistas.

Con independencia de las secuelas del 98, los múltiples disturbios que originaron el estado de guerra en todo el país, y el regreso de los últimos soldados derrotados de Filipinas, el Madrid que estrenaba el nuevo siglo se convertirá en el espacio en el que se forjaron las alianzas y se exhibieron los atributos de poder de las familias que componían unas elites que tenían la aspiración de dominar a toda la nación ${ }^{1}$. Además, y pese a la tensa situación brevemente apuntada, determinados acontecimientos de carácter político-social tendrían lugar en la capital del reino y concitarían la atención de escritores, artistas plásticos o fotógrafos pictorialistas $^{2}$ : la jura como rey de Alfonso XIII (1902) y la precedente boda de la princesa de Asturias con Carlos de Borbón (1901), entre otros menos relevantes.

En este ambiente artístico de entresiglos en el que se abrían hueco las nuevas teorías del Modernismo, se sitúan los dos personajes que por su relación atraen ahora nuestro interés: Antonio Portela Paradela y Gonzalo Bilbao Martínez.

El primero, La Coruña, 1865-1927, un lustro más joven que el sevillano, se había formado en la Escuela de Bellas Artes de su ciudad natal ("El Consulado") con maestros como Isidoro Brocos (1841-1914), compañero de Ruiz Blasco, padre de Picasso, quien además fue alumno suyo. También fue discípulo y amigo

${ }^{1}$ ARTOLA BLANCO, Miguel: El fin de la clase ociosa: De Romanones al estraperlo. 1900-1950. Madrid, 2015.

${ }^{2}$ Conviene recordar que el pictorialismo es el término que se usa para calificar a un movimiento fotográfico de carácter artístico que se desarrolla a nivel mundial, sobre todo en Europa, Estados Unidos y Japón, entre fines de 1880 y 1918-20. La denominación parte del vocablo inglés picture (imagen, cuadro, pintura, fotografía) y no de paint (pintura), de tal modo que -según algunos- es incorrecto hablar de fotografía pictórica o pictoricista, nombres que vendrían a referirse a la fotografía académica, tendencia que se encuentra muy relacionada con la pintura.

El inicio del movimiento se relaciona con la publicación en 1889 del libro de Peter Henry Emerson, Naturalistic Photography, en el que se refería al status artístico de la fotografía negado por algunos.

El pictorialismo selecciona los temas como objetos fotográficos, entre los que prevalece el paisaje en situaciones naturales de días nublados, de lluvia, de niebla, y aquellos otros en los que los elementos atmosféricos impiden que las imágenes sean nítidas e introducen borrosidad en la representación. Igualmente, el retrato, para el que se prefieren figuras femeninas, generalmente envueltas en borrosidad. También son objetivos del pictorialista las escenas alegóricas, y otras de similares características.

En España tuvo cierto arraigo en los primeros años del siglo XX, en manos de autores como Antonio Cánovas del Castillo, Carlos Iñigo, Luis de Ocharán, Antonio Escobar, Hernández Briz, Antonio Rabadán, Francisco Toda, Antonio Prats y Antonio Portela, que eran miembros de la Real Sociedad Fotográfica Española y contribuyeron a fomentar y prestigiar un tipo de fotografía de imágenes alegóricas y mitológicas, inspiradas en asuntos propios de la pintura y en temas literarios. 
del militar y profesor Román Navarro García de Vinuesa (1854-1928). Tuvo igualmente compañeros escolares que ejercerían gran influencia sobre él y compartirían su estancia madrileña desde su establecimiento en la capital en 1897: Francisco Llorens (1874-1948), José Nombela, José Gómez Villardefrancos y, sobre todo, Joaquín Vaamonde Cornide (1872-1900) (Figura 1). A través suya, Portela conoce a la afamada escritora Emilia Pardo Bazán ${ }^{3}$. También por su mediación emprenderá viaje a Hispanoamérica: Cuba, Méjico y Argentina en donde seguiría desarrollando su trabajo fotográfico y pictórico ${ }^{4}$. También Portela se relacionó con la escritora y compatriota Rosalía de Castro, a la que retrató en alguna ocasión como pintor y fotógrafo (Figura2).

Por su parte, Gonzalo Bilbao (Sevilla, 1860-Madrid,1938), gozaba de una destacada posición social en su ciudad natal que se prolongaría muy pronto a Madrid auspiciada sobre todo por su simpatía hacia la causa monárquica alfonsina ${ }^{5}$. Esto le proporcionó el conocimiento, la relación y la amistad con distinguidas familias de las clases acomodadas deseosas de ser retratadas por el maestro que empezaba a compartir con Sorolla -éste, diez años ya de su llegada-y alguno más los encargos en este género. Ambos, sevillano y valenciano respectivamente y casi de la misma edad, encontraron en la villa y corte de principios de siglo la clientela que les mantuvo en un estatus y nivel de vida privilegiados. No fueron los únicos, pues la colonia de intelectuales, escritores y artistas se fue incrementando con los llegados desde la periferia coincidiendo con el fin de siglo. La Real Academia de San Fernando, su Escuela, todavía vinculadas a la tradición académica, y el Círculo de Bellas Artes, más afín a las nuevas teorías modernistas, eran los promotores entonces de la cultura, y las casas de las familias acomodadas los cenáculos en donde se pactaban los encargos artísticos ${ }^{6}$.

${ }^{3}$ Fue la protectora de Joaquín Vaamonde, quien la retrató en varias ocasiones, y en cuyo pazo de Meirás moriría en 1900.

${ }^{4}$ Agradezco a D. Moisés Acción Portela las noticias biográficas que me facilita de su bisabuelo Portela Paradela.

${ }^{5}$ Fue elegido presidente del Ateneo y Sociedad de Excursiones de Sevilla en junta general celebrada el 15 de noviembre de 1901, institución de la que era vicepresidente desde mayo de ese mismo año. Sin embargo, renunciaría al año siguiente figurando solo como vocal para atender a sus compromisos capitalinos. Para todo lo relativo al artista, véanse nuestros trabajos, en especial el libro: Gonzalo Bilbao, el pintor de las cigarreras. Madrid, 1989.

${ }^{6}$ Precisamente, Gonzalo conocería a su futura esposa, con la que contrajo matrimonio en 1904, en torno al círculo en que se movía el pintor y gastrónomo Agustín Lhardy, tío de María Roy Lhardy y amigo de la élite madrileña. Su magnífico restaurante haría las delicias de los renombrados gustos culinarios de intelectuales, escritores y artistas vinculados al Centro Gallego, de la que era presidenta de honor Emilia Pardo Bazán y Antonio Portela vocal de su directiva. 
Ambos artistas se relacionaron con los círculos intelectuales y artísticos madrileños en torno a 1900 frecuentados por escritores y artistas periféricos que venían a la capital en busca de oportunidades, muchos de los cuales las encontrarían en las Exposiciones Nacionales de Bellas Artes y en los certámenes que celebraban los centros, círculos y salas de exposiciones de carácter privado.

Portela estableció su estudio, llamado en principio Sociedad Artístico Fotográfica y después Portela y Cía, en pleno centro neurálgico de la capital: calle Alcalá, 4 , concretamente en un espléndido ático, $5^{\circ}$ piso con una galería canovista ${ }^{7}$, precisamente en donde se instaló en 1850 el célebre fotógrafo Charles Clifford (Gales, c. 1820-Madrid, 1863).

Tal vez por ser socio fundador en 1899 de la Real Sociedad Fotográfica ${ }^{8}$, Portela fue nombrado fotógrafo de la Casa Real, retratando en diversas ocasiones a Alfonso XIII ${ }^{9}$. Se convertiría así en el pictorialista más acreditado de la vida mundana del Madrid brillante y aristocrático de la monarquía alfonsina; de la burguesía acomodada de artistas y escritores (Figuras 3 y 4); de las escenas del más grato dandismo y sugestiva frivolidad; y del Madrid burgués y callejero. Pero también el fotógrafo doméstico y de la vida cotidiana que plasmó situaciones o acontecimientos diarios o excepcionales (Figuras 5 y 6) ${ }^{10}$.

Gonzalo Bilbao, por su parte, arribaba a Madrid con frecuencia al objeto de retratar y exponer, pero también para visitar a amigos y compañeros, sobre todo a Agustín Lhardy (Madrid, 1847-1918) ${ }^{11}$. Alternaba ésta con su presencia en Sevilla en la que tenía compromisos artísticos e institucionales ${ }^{12}$. De la misma manera,

${ }^{7}$ La galería con mejor luz para un retrato es la del insigne maestro Antonio Portela... Porque la galería de Portela es muy baja de techo. (Revista "La Fotografía", febrero de 1904). Sobre el portón de su estudio mandó erigir una expresiva visera modernista.

En estos años era frecuente establecer los estudios de esta clase en los pisos más altos para favorecer la entrada de luz.

${ }^{8}$ Entre los miembros de esta sociedad, que en principio era la sección fotográfica del Círculo de Bellas Artes, figuraban por entonces: el Conde de Agüera, el Conde de Aldana, el Conde de Belchite, Antonio Cánovas del Castillo y Santiago Ramón y Cajal.

9 Una de las más interesantes tomas fue la que realizó en 1903 en la galería principal del Palacio Real en que aparece el joven monarca rodeado por trece mandos de los ejércitos de tierra y marina en traje de gala. Véase: GONZÁLEZ CRISTÓBAL, Margarita y RUIZ GÓMEZ, Leticia: La Fotografía en las colecciones reales. Madrid, 1999.

${ }^{10}$ Hacemos alusión a algunos trabajos en ambas líneas como son el autorretrato al carboncillo (s/d.) que también pasaría al cliché, y el excepcional acontecimiento del eclipse de sol ocurrido el 28 de mayo de 1900 visto por Portela y su familia desde la azotea de su estudio madrileño.

${ }^{11}$ Vid nota 5.

12 Además de ejercer su magisterio en la Escuela de Artes, Industria y Bellas Artes de Sevilla, en 15 de noviembre de 1901 fue elegido presidente del Ateneo y Sociedad de 
viajaba al extranjero para participar con éxito en algún certamen de carácter internacional ${ }^{13}$.

Entre Portela y Bilbao hubo algunos nexos que le acercarían hasta el encuentro de 1901. Nos referimos a la relación profesional e incluso personal en el caso del sevillano que mantuvieron con la familia real y con la nobleza y aristocracia madrileñas ${ }^{14}$. También la importante colaboración desde 1900 de Portela en la sección "Las Crónicas Gráficas” (Resumen de las mejores fotografías de la temporada) de la Revista Blanco y Negro, fundada en 1891 por el sevillano Luca de Tena, amigo de la familia Bilbao ${ }^{15}$.

Los halagüeños presagios que rodearon al nuevo siglo en Europa tuvieron su reflejo en la Exposición Universal de París de 1900 (abril-noviembre), en la que causó sensación la iluminación artificial que hizo bueno el slogan turístico de la capital del Sena, pues la electricidad conseguía materializar el ideal de la Ilustración Francesa y la claridad mental del pensamiento racionalista, demostrando que la nación abanderaba con brillantez la nueva centuria. La presencia del cinematógrafo de los Lumière y sus variedades el cinéorama y el mareorama justificaban con creces este certamen, por lo que la fotografía fue objeto de una magna muestra en la que intervinieron los más acreditados maestros de tan moderna especialidad artística. Antonio Portela participó con éxito obteniendo medalla de oro y diploma con una fotografía de desnudo correspondiente al grupo tercero, clase doce, fotografías y fototipias ${ }^{16}$.

Al mismo tiempo que París y tal vez aprovechando esos vientos favorables que soplaban desde Francia, la célebre y elegante Casa Amaré sita en la madrileña calle de Alcalá cerca del estudio fotográfico de Portela, estaba celebrando como galería de exposiciones una muestra de pintura en sus elegantes salones de

Excursiones de la ciudad del que ya era vicepresidente, y al que tuvo que renunciar al año siguiente por sus muchas ocupaciones permaneciendo como mero vocal.

${ }^{13}$ En 1897 acudió al Salón de París, en donde obtuvo segunda medalla hors concurs, y dos años después medalla de oro en la Internacional de Berlín.

${ }^{14}$ Por el estudio del fotógrafo pictorialista pasaron la flor y nata de la sociedad madrileña; entre otros: Joaquín Sorolla, Emilia Pardo Bazán, Blanca Quiroga, Marquesa de Cavalcanti, Loreto Prado...

${ }^{15}$ Hizo una interesante serie en las que se recogían, entre otras: fotografías del frontón de la Biblioteca Nacional; de barcos varados en la costa; del monumento a Bolognesi y la estatua de Quevedo hechos por Agustín Querol, etc. (Véanse los números correspondientes a: 9/VII/1898; 12/X/1901/; 10/V/1902; 2/V/1903 y 27/VI/1903).

SÁNCHEZ VIGIL, Juan Miguel: La fotografía en España... Summa Artis. Espasa Calpe. Madrid, 2001, pp. 346 y 382.

${ }^{16}$ LÓPEZ MONDÉJAR, Publio: Historia de la fotografía en España. Fotografía y sociedad desde sus orígenes hasta el siglo XXI. "La Ilustración Artística", 19/III/1900; "La Correspondencia de España", 10/VII/1900; "La Época", 13/VII/1900; "Nuevo Mundo", 24/X/1900. 
muebles eclécticos y modernistas ${ }^{17}$. Llegó a ser -al decir de Balsa de la Vega- la mejor exposición presentada en Madrid en los últimos veintiséis años. Siguiendo a este crítico, nos podemos hacer una idea de lo que podía ser un certamen no oficial en el ámbito del arte "pompier"18. Se componía de dos salas, para llegar a la primera se atravesaba por un espacio ocupado por exquisitos muebles de elegante y original traza, divanes, sillones, armarios-vitrinas y muros decorados por ricos tapices $^{19}$. Pues bien, en esta muestra se exhibieron obras de destacados pintores como el propio Gonzalo Bilbao, Joaquín Sorolla, Cecilio Pla, Raimundo de Madrazo y Marcelino de Santa María, entre otros, y no menores escultores como Mariano Benlliure o Miguel Blay.

1901 llegaría a ser un año muy fecundo en el ambiente artístico madrileño. En plena primavera, abría el calendario de acontecimientos artísticos la Exposición Nacional de Bellas Artes, una de las mejores desde la creación del certamen oficial en 1856, que fue inaugurada el 21 de abril en el Palacio de las Artes e Industrias con asistencia de los reyes y se clausuró el 24 de junio. Supuso la consagración como pintor, después de Sorolla, de Gonzalo Bilbao, que fue premiado con medalla de primera clase por el conjunto de obras presentadas ${ }^{20}$. Respondía a la diversidad temática del artista en esos momentos: paisajes plenearistas y cuadros de asuntos sociales.

Seis días después de clausurarse, la propia Casa Amaré convocó su primer concurso fotográfico, todo un acontecimiento en Madrid tras la Exposición Universal de París ${ }^{21}$.

Se mostraron obras de fotógrafos pictorialistas y de pintores que también practicaban el arte fotográfico como Valentín de Zubiaurre. Triunfó rotundamente

${ }^{17}$ Fue fundada por Francisco Amaré en 1890 pero regentada por sus hijos Enrique (director artístico y ebanista y pintor decorador), Rafael (ebanista y escultor decorador) y José (director económico), Véase: DA ROCHA ARANDA, Oscar: El Modernismo en la arquitectura madrileña. Génesis y desarrollo de una opción ecléctica. Madrid, 2009, p. 205.

18 "La Ilustración Española y americana”. Madrid, 15 de agosto de 1900, n 11, p. 174.

${ }^{19}$ De forma trapezoidal y totalmente tapizadas sus paredes de seda, se evidencia aquí la preocupación por el problema de la iluminación... Al parecer y en línea con experimentaciones llevadas a cabo en la Sociedad de Acuarelistas de Londres (luz eléctrica moderada por gruesas telas blancas), se utilizaron lámparas veladas con tules al objeto de eliminar brillos y dar la apariencia de luz diurna. (BERNAL MUÑOZ, José Luis: "Museos y exposiciones en el cambio de siglo. 1897-1903". Cuadernos de Arte e Iconografía. F.U.E. Tomo III. 6, 1990).

${ }^{20}$ Fueron, entre otras, las tituladas: "El puente de Triana en una tarde de verano", "Efecto de sol en una huerta" y "El último recurso". Su futuro tío político, Agustín Lhardy, obtuvo en este certamen una segunda medalla por su obra "Primavera". Vid: PÉREZ CALERO, Gerardo: op. cit., y PANTORBA, Bernardino: Historia y crítica de las Exposiciones Nacionales de Bellas Artes celebradas en España. Madrid, 1980, pp. 176 y 182.

${ }^{21}$ Téngase en cuenta que la fotografía aún no formaba parte de ninguna sección en los certámenes oficiales y pertenecía al ámbito privado. 
Antonio Portela, que obtuvo la medalla de oro y el diploma de primera clase por varios ejemplares presentados ejecutados con complejas técnicas al nitrato de urano, al percloruro de hierro y mixtas. Entre ellos, destacaba el que reproducía un retrato de cuerpo entero de una hermosa joven. También expuso otros ejemplares en dos tonos y un tema de flores.

Decía al respecto un crítico contemporáneo: El elegante Salón de Bellas Artes que en la calle de Alcalá tienen instalados los infatigables hermanos Amaré está actualmente ocupado por una notabilísima exposición de fotografías, a la cual han concurrido cuantos notables "amateurs" tiene en España el difícil sport y arte de Daguerre. Las paredes del elegante salón que se vieron cubiertas de notables obras pictóricas de los Ferrant, Sorolla, Bilbao, Muñoz Degrain, Viniegra y otros tantos ilustres artistas, se ven hoy totalmente ocupadas por notables fotografias, verdaderas obras de arte, por la artística manera de componer que han tenido los notables operadores que concurren a la citada exposición.

[...] También Portela presenta varios retratos en dos tonos, y unas flores que dan una excelente idea del gusto artístico de su autor y de su gran habilidad fotográfica.

La inauguración de tan interesante exposición, se verificó con asistencia de numerosas señoras artistas, "amateurs" y periodistas que fueron obsequiados con la esplendidez proverbial en casa Amaré.

Para terminar, daré una buena noticia a los expositores.

Los diplomas de los premios serán ilustrados por Alejandro Ferrant, Emilio Sala, Joaquín Sorolla, Gonzalo Bilbao y demás currinches de los pinceles y la paleta $^{22}$.

Nos interesa precisamente el diploma que obtuvo Portela elaborado por Gonzalo Bilbao (Figura 7). Se trata de una composición a la aguada cuya iconografía hace alusión al arte de la fotografía. De tal modo, un grupo de graciosos y juguetones angelotes se divierten: uno montado como si cabalgase sobre una cámara fotográfica de trípode; otro, contemplando una fotografía, y el resto se solaza con coronas de triunfo y guirnaldas. El autor evoca los prototipos de diplomas con alegorías de las artes y de las letras que venían haciéndose en Sevilla desde el último cuarto del XIX siguiendo la senda de Jiménez Aranda ${ }^{23}$. En este sentido, aunque manifiesta motivos iconográficos vinculados a la estética neobarroca, hace también ciertas incursiones en la decoración modernista con la que tiene referencia.

${ }^{22}$ ZOZAYA, Luis: "Sport Fotográfico. Exposición Amaré”, La correspondencia de España. Madrid, domingo 2 de junio de 1901.

${ }^{23}$ Este tenía entonces la misma edad que Gonzalo Bilbao cuando llevó a cabo el diploma que concedió la Academia Libre de Bellas Artes al músico Fernando Palatín en 1878. Véase nuestro trabajo: "A propósito de la Academia Libre de Bellas Artes de Sevilla" Laboratorio de Arte, 6, 2014, pp. 471-478. 
La trayectoria que siguieron con posterioridad ambos artistas estuvo plagada de éxitos, pero excede ya las intenciones y límites de este trabajo.

Fecha de recepción: 30 de septiembre de 2015.

Fecha de aceptación: 20 de noviembre de 2015.

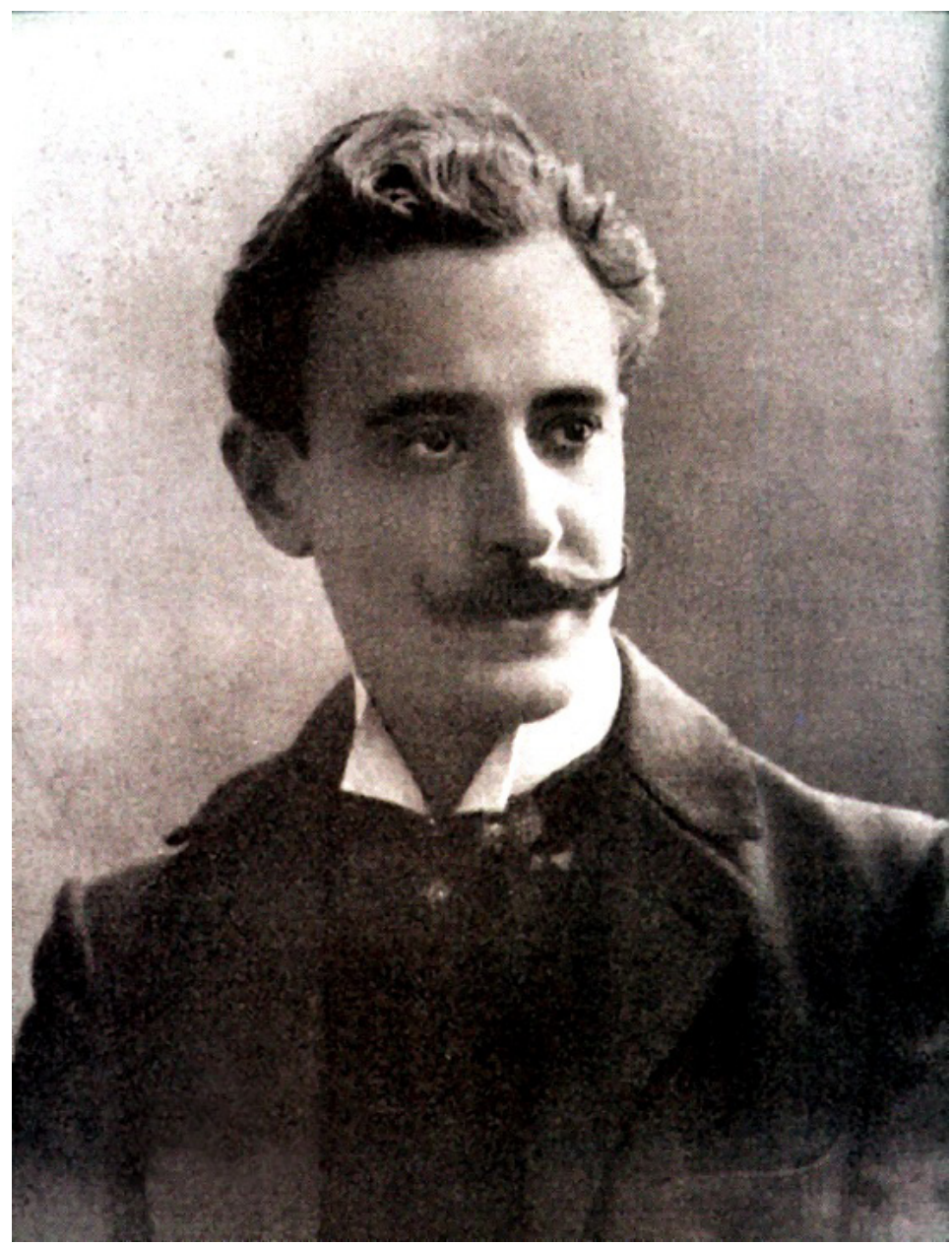

Figura 1. Portela. Vaamonde Cornide, 1897. 


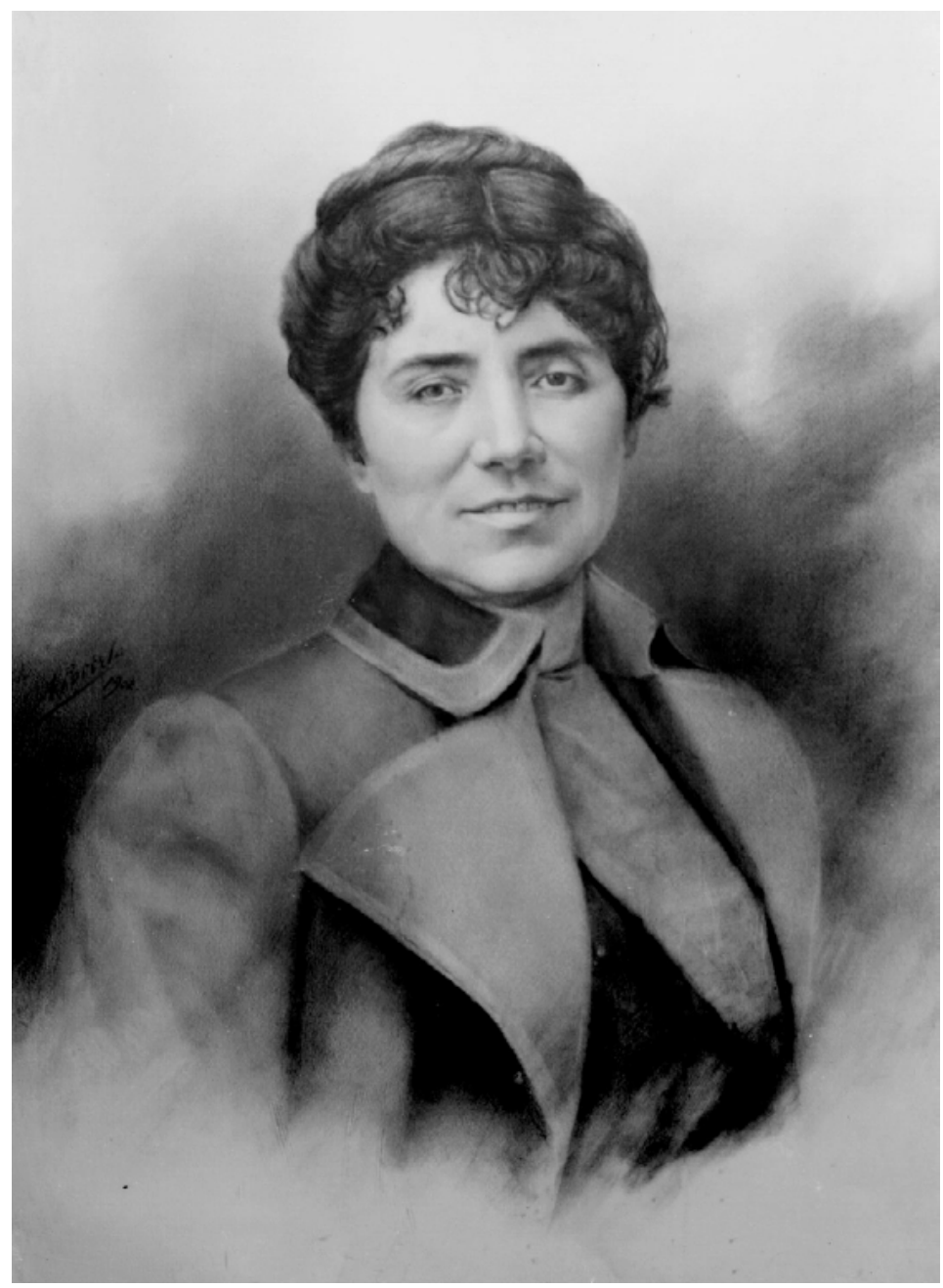

Figura 2. Portela. Dibujo de Rosalía de Castro, 1902. 


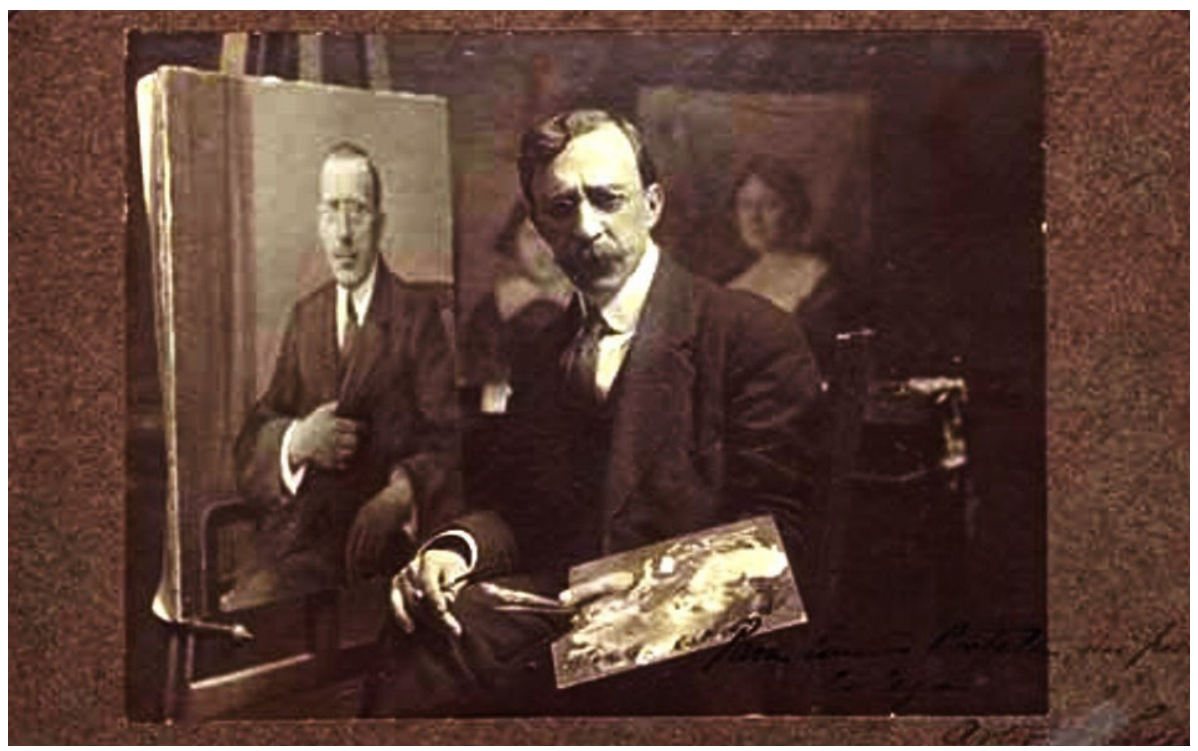

Figura 3. Portela. Retrato del pintor Arturo Fernández Cersa. S/d.

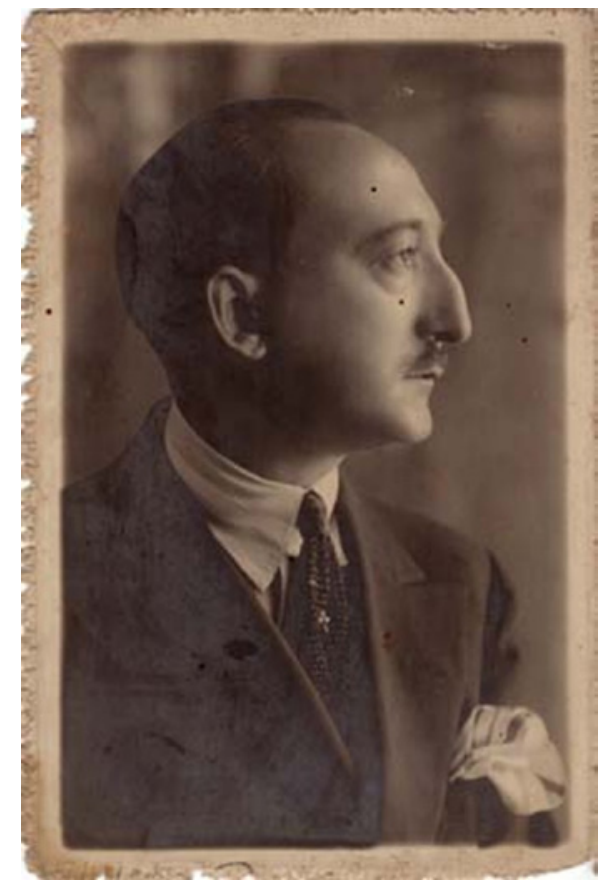

Figura 4. Portela. Wenceslao Fernández Flores. S/d.

LABORATORIO DE ARTE 28 (2016), pp. 499-510, ISSN 1130-5762

e-ISSN 2253-8305 - DOI http://dx.doi.org/10.12795/LA.2006.i.01.26 
Figura 5. Autorretrato al carboncillo. S/d.
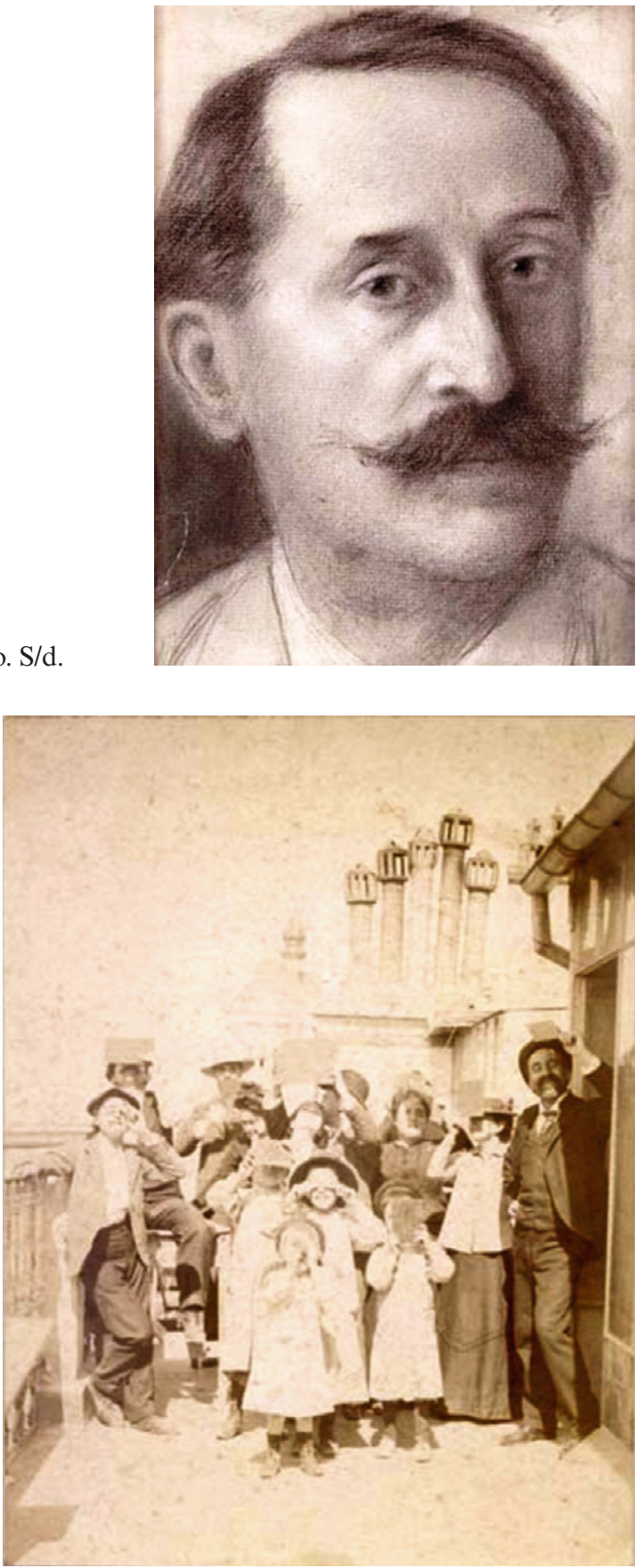

Madrid. 28/V/ 1900. 


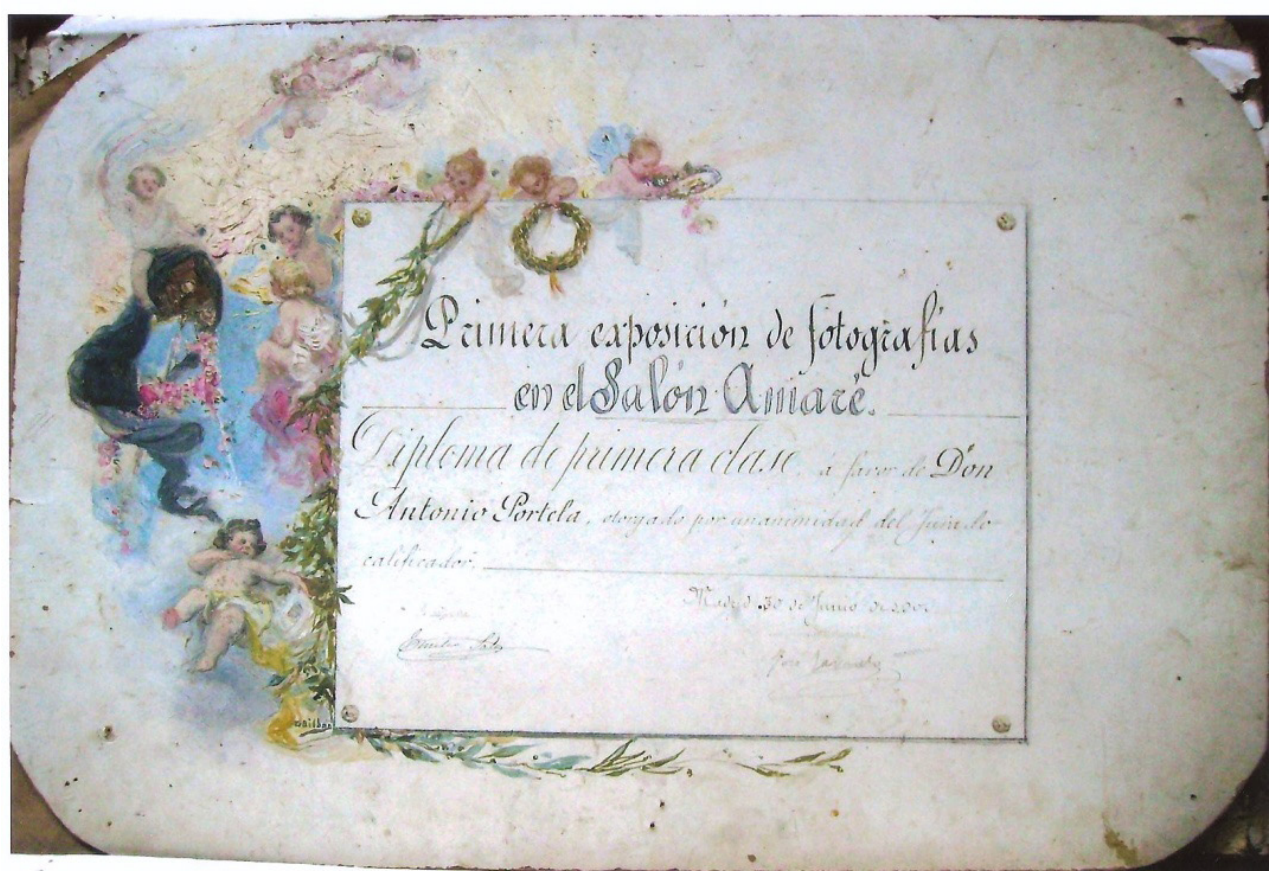

Figura 7. Gonzalo Bilbao. Diploma de primera clase a favor de Antonio Portela. 1901. 